\title{
Cronkhite-Canada syndrome: case description
}

\author{
Andrea Da Porto, Liana Domenis, Cristina Quaglio, Piero Brosolo, Vito Di Piazza \\ SOC Medicina Generale, AO S. Antonio Abate, Tolmezzo, ASS 3 Alto Friuli, Italy
}

\begin{abstract}
We present the case of an 80-year old woman affected by the Cronkhite-Canada syndrome. This rare disease was described for the first time in 1955. It is characterized by the growth of multiple polyps in the gastroenteric tract, leading to diarrhea, alopecia, dystrophy of nails and hyper-pigmented skin. In this article, we describe the patient's clinical picture and report the results of laboratory tests and imaging assessments.
\end{abstract}

\section{Introduction}

The Cronkhite-Canada syndrome (CCS) is a rare disease characterized by generalized gastrointestinal polyps associated with hyperpigmentation, hair loss, and dystrophic changes in the fingernails. It was first reported and described by Cronkhite and Canada in 1955. ${ }^{1}$ To date, only about 400 case reports of CCS exist in the worldwide literature. The etiology of CCS remains largely unknown. Although fatigue and mental stress are the most commonly cited potential causes, surgery, pregnancy, radiotherapy, and alcoholism have been proposed as potential contributing factors. ${ }^{2} \mathrm{CCS}$ is mainly diagnosed on the basis of its clinical manifestations and indicative histological findings, including generalized gastrointestinal polyps associated with ectodermal changes. Because of its rarity and lack of symptom control, the most efficacious therapy remains to be determined. In the literature, CCS treatment includes symptomatic and support therapy, administration of corticosteroids, antibiotics and acid inhibitors, therapeutic endoscopy, and surgery.

Correspondence: Andrea Da Porto, via Nino Bixio 23, 33100 Udine, Italy.

E-mail: andrea daporto@tin.it

Key words: Cronkhite-Canada syndrome, colon polyposis, alopecia, nail distrophy, hypogeusia.

Conflict of interests: the authors declare no conflict of interests.

Received for publication: 4 September 2013.

Revision received: 13 December 2013.

Accepted for publication: 30 December 2013.

This work is licensed under a Creative Commons Attribution NonCommercial 3.0 License (CC BY-NC 3.0).

CCopyright A. Da Porto et al., 2014

Licensee PAGEPress, Italy

Italian Journal of Medicine 2014; 8:135-139

doi:10.4081/itjm.2014.428

\section{Case Report}

We report a case of an 80-year old woman, admitted to the emergency ward of our hospital and then to our internal medicine ward. She came to our Emergency Room reporting sudden heart palpitations. These symptoms occurred, while she was experiencing a diahrroic syndrome. After hospital admission, the presence of hypokalemia was detected; therefore she was supplemented with an IV potassium-chloride solution to quickly resolve the arrhythmia.

The patient's clinical history included the following symptoms: hypoageusia, dyspeptic disorders, diahrroic bowels, weight loss by about $10 \mathrm{~kg}$, progressive alopecia (Figure 1) and nail dystrophy (Figure 2) with the loss of all nails in hands and feet. Therefore, the patient had already had a number of medical tests. The laboratory tests revealed mild anemia, vitamin B12 deficit, hyperphosphatemia, slightly higher levels of parathyroid hormone (PTH) and gastrin (during therapy with proton pump inhibitors). A screening program to test the presence of an autoimmune status was negative (antinuclear antibodies, C3, C4). An upper endoscopy showed that the esophagus was normal, the gastric mucosa (Figure 3) was very hyperemic, edematous, thick and grainy and there were also some converging folds close to each other towards the pylorus. A small polyp was removed for an histology report. The duodenal mucosa presented a similar macroscopic appearance. The histological report, performed on the gastric polyp showed the presence of a fundic gastric mucosa, where a chronic gastritis was observed, together with a slightly dilated cystic gland. Helicobacter pylori was not detected. In the duodenal specimen, histological evaluation showed chronic inflammation, gastric metaplasia, infiltration of lymphoid T cells (CD3+) and detected several enterochromaffin-like cells. Immunohistochemistry for chromogranin was positive. In order to exclude the existence of a gastrinoma, a somatostatin 
receptor scintigraphy (Ocreoscan) was performed, but it was negative. Abdominal ultrasound did not show significant alterations.

An ultrasound of the neck was performed, after detection of PTH increase; however no remarkable alterations were observed.

Furthermore, the patient reported a history of osteoporosis of the spine and femur diagnosed by dual-energy X-ray absorptiometry and open-angle glaucoma.

After admission to our unit, the patient continued to receive supplementations of potassium chloride, until her values normalized. Since then the patient maintained a regular sinus rhythm and did not experience other episodes of palpitations. Blood tests showed hypokalemia, hypomagnesaemia, hypophosphoremia, reduced serum levels of zinc, vitamin B12, Vitamin D 25 $\mathrm{OH}$ and hypoalbuminemia (Table 1). There was a slight increase in inflammatory markers. A 24-h urine collection was performed to detect protein, potassium, phosphate and calcium urinary excretion. This test showed reduced levels of all these electrolytes. On the basis of the patient's symptoms and signs as well as the results of her serum/imaging tests and histological assessment, we supposed that she might be suffering from a CCS syndrome. Therefore a colonoscopy was requested. Endoscopic examination confirmed the presence of the typical macroscopic pattern, consistent with CCS. The endoscopic procedure detected a diffuse polyposis (with small polyps) involving in particular the transverse and right colon and the presence of numerous micro polyps in the cecum and of the ileocecal valve (Figure 4). The histological examination demonstrated the presence of an edema of the lamina propria, inflammatory infiltration of lymphocytes and cystic dilatation of the glands.

According to hypothesis of Sweetser et al., ${ }^{3}$ the levels of sub-classes of immunoglobulin IgG were measured (Table 1) and a considerable increase in the fraction of IgG4 was found. Steroid treatment with Prednisolone $50 \mathrm{mg} /$ die was started and with vitamins and microelements supplementation, inducing a rapid reduction of asthenia and a quick recovery in appetite and regular bowel movements. The dosage of the steroid was gradually decreased down to a maintenance dose $(5 \mathrm{mg} / \mathrm{die})$. After about 60 days of treatment, an overall significant improvement in the patient's conditions was observed with the restoration of regular bowel movements, and a $5 \mathrm{~kg}$ weight gain, re-growth of hair and nails and a partial recovery of taste. Table 2 shows the reported laboratory findings after a 60-day treatment. ${ }^{4}$

\section{Discussion}

The Cronkhite-Canada syndrome is a rare form of gastrointestinal polyposis, described for the first time in $1955^{1}$ and is characterized by widespread gastroin- testinal polyps, ectodermal tissue alterations, such as alopecia, onychodystrophy and hyperpigmentation. To date about 500 cases have been documented and described, $75 \%$ of them in the Japanese population. ${ }^{5}$ The

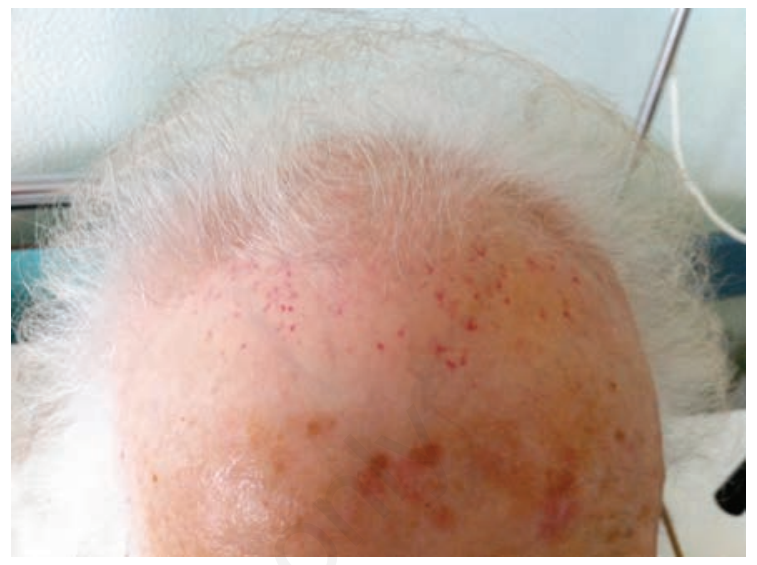

Figure 1. Alopecia.

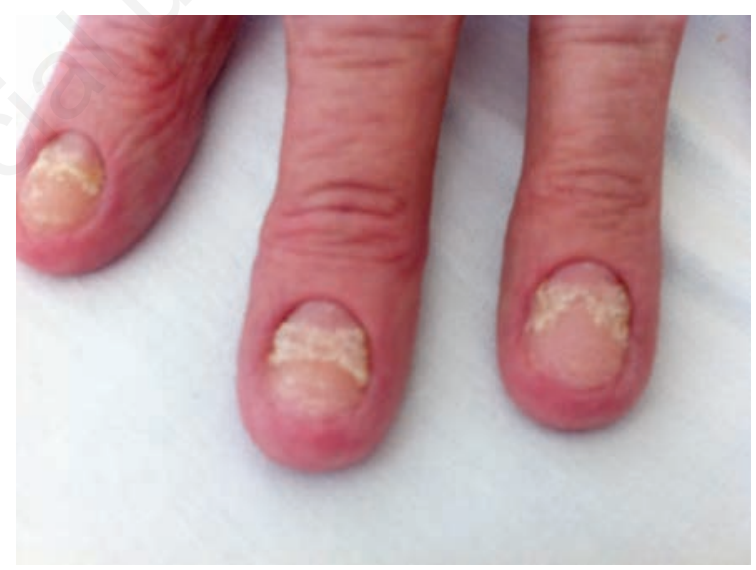

Figure 2. Nail dystrophy.

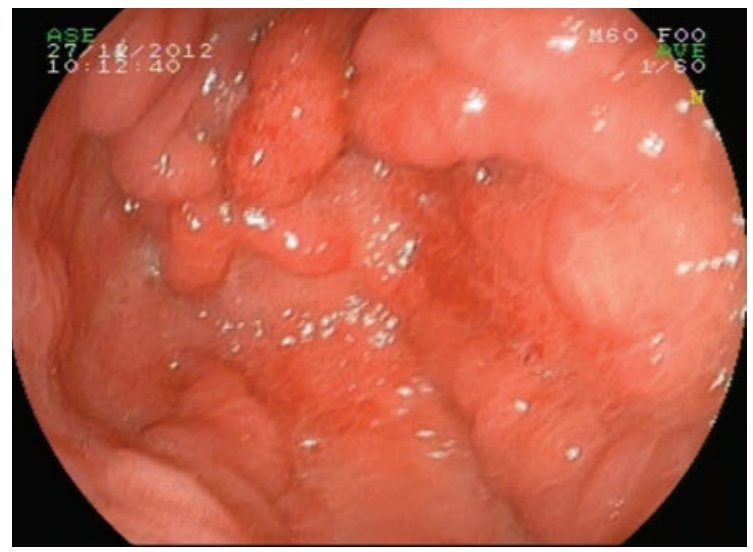

Figure 3. Gastric mucosa. 
ratio between males/females is $3: 2$. This condition tends to occur in adult/old age, with a mean of about 60 years of age. ${ }^{6}$

Although fatigue and mental stress are the most commonly reported potential causes, surgery, pregnancy, radiotherapy, and alcoholism have been proposed as potential contributing factors. ${ }^{2}$ The first most common symptoms are: dyspeptic disorders, diarrhea and change in bowel habits, hypogeusia, significant weight loss and signs (glossitis, numbness in the limbs, xerophthalmia, xerostomia), which are likely to be secondary to vitamin and mineral deficiency. According to a study, enrolling 110 patient with CCS, which was performed in the Japanese population by Goto, ${ }^{2} 5$ subtypes of this syndrome were described on the basis of clinical symptoms (Table 3 ). Our case can be classified as the uncommon variant subtype II of CCS. This condition is characterized by hypogeusia, nail dystrophy, alopecia which coexist in the absence of hyperpigmentation.

The disease is often associated with a protein-loosing enteropathy, caused by an excessive mucous secretion of the intestinal crypt cells, leading to hypoproteinemia, malnutrition and electrolyte disorders. ${ }^{7}$ The most commonly described serum alterations are: electrolyte disorders (hypokalemia, hypomagnesemia), mineral and vitamin deficiencies (zinc, copper, selenium, vitamin $\mathrm{A}, \mathrm{D}, \mathrm{E})$, hypoproteinemia and ipoabuminemia. ${ }^{8,9}$

The macroscopic characteristics of the mucosal alterations can be detected by means of endoscopic exams and include hyperemia and grainy gastric mucosa with the presence of rare hyperelastic micropolyps and the presence of multiple polyposis on the colon. The polyps are usually small $(1 \mathrm{~mm}-3 \mathrm{~cm})$ and mainly sessile. ${ }^{10}$ The esophagus is usually unaffected. The typical histological feature is represented by gastritis and chronic duodenitis with gastric metaplasia involving the duodenum mucosa. The polyps (both gastric and of the colon) usually present histologic alterations, such as edema of the lamina propria, inflam- matory infiltrate and cystic swelling of the glands. ${ }^{7-9}$

If we consider non-hereditary clinical entities, which are characterized by gastrointestinal polyps, the differential diagnosis must be done considering hyperplasic juvenile polyposis (presence of numerous polyps spread in the colon) and symptoms that can often be similar but the absence of typical ectodermal alterations, such as alopecia, hyper pigmentation and onicodistrophia, makes the diagnosis usually simple. Furthermore, one must keep in mind that the syndrome of Peutz-Jeghers, Cowden disease and adenomatous polyposis have common signs and symptoms. Appropriate laboratory and imaging tests as well as clinical assessment of patients may help differentiate these syndromes and/or diseases (Table 2).

Autoimmune mechanisms may be involved in CCS pathogenesis. A study performed by Sweetser et $a l .{ }^{3}$ on 14 patients of the Mayo Clinic showed the presence of high levels of immunoglobulin IgG4 (associated to autoimmune diseases) due to polyps of the colon. Our observation of increased serum IgG4 levels in this subject is consistent, although indirectly, with the hypothesis that CCS may have an autoimmune

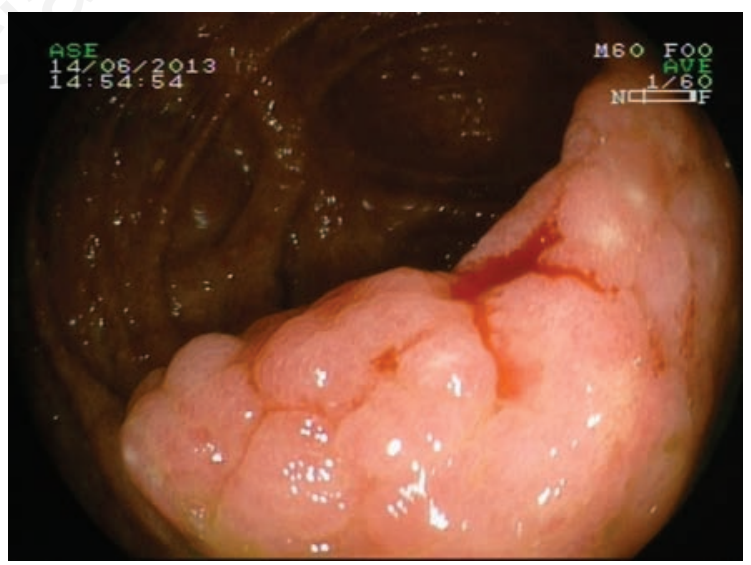

Figure 4. Colon mucosa.

Table 1. Laboratory findings.

\begin{tabular}{lcc}
\hline Laboratory variable & Value & Normal range \\
\hline Total protein $(\mathrm{g} / \mathrm{dL})$ & 5.7 & $6.2-8.7$ \\
Serum albumin $(\mathrm{g} / \mathrm{dL})$ & 3.16 & $4-4.76$ \\
$25 \mathrm{OH}$ vitamin D (nMol/L) & 22 & $62-199$ \\
Vitamin B12 & 183 & $190-700$ \\
Ferritin $(\mathrm{pMol} / \mathrm{L})$ & 89 & $54-755$ \\
Copper $(\mathrm{uMol} / \mathrm{L})$ & 10.5 & $11.8-22$ \\
Zinc $(\mathrm{uMol} / \mathrm{L})$ & 8.4 & $9-15.7$ \\
Potassium $(\mathrm{mEq} / \mathrm{L})$ & 2.6 & $3.3-5.4$ \\
Magnesium $(\mathrm{mg} / \mathrm{dL})$ & 1.5 & $1.5-2.6$ \\
Total IgG $(\mathrm{mg} / \mathrm{dL})$ & 813 & $740-1440$ \\
IgG4 $(\mathrm{mg} / \mathrm{dL})$ & $126(15.5 \%$ of total $\mathrm{IgG})$ & $1.6-6.8 \%$ of total $\mathrm{IgG}$ \\
\hline
\end{tabular}


genesis. On the other hand, epidermal disturbances have not been correlated with an autoimmune origin. In a recent article it was demonstrated that hair follicles of the scalp show no evidence of histological alterations or inflammatory lesions. ${ }^{11}$ It is therefore assumed that the ectodermal tissue alterations may be caused by malabsorption of micronutrients and minerals, such as zinc and iron.

Due to the rarity of the syndrome, the possible therapeutic strategies documented up to now are not univocal and there is no evidence-based therapy. ${ }^{12}$ The autoimmune pathogenetic hypothesis has led many authors to use steroid therapy, resulting in a satisfactory high percentage of clinical response. Treatment scheme generally includes prednisone 40 $\mathrm{mg}$ for 7 days with a progressive tapering to $5 \mathrm{mg}$ per week, and then it should be withdrawn. With this regimen Sweetser et al. obtained clinical remission after 3 months of therapy in 10/11 cases. ${ }^{3}$ Cases of recurrences were observed, once the steroid therapy

Table 2. Differential diagnosis of polyposis colonic syndromes.

\begin{tabular}{|c|c|c|c|c|c|c|}
\hline Syndrome & $\begin{array}{l}\text { Age onset } \\
\text { (years) }\end{array}$ & Transmission & $\begin{array}{l}\text { Distribution } \\
\text { of polyps }\end{array}$ & Histology & $\begin{array}{l}\text { Extra-intestinal } \\
\text { manifestation }\end{array}$ & Prognosis \\
\hline $\begin{array}{l}\text { Hyperplastic } \\
\text { polyposis }\end{array}$ & $>40$ & $\begin{array}{l}\text { Autosomal } \\
\text { Dominant }\end{array}$ & Colon & $\begin{array}{l}\text { Hyperplastic polyps, } \\
\text { sessile serrated adenomas }\end{array}$ & None & Colon cancer \\
\hline $\mathrm{CCS}$ & $50-60$ & Sporadic & $\begin{array}{l}\text { Stomach, } \\
\text { small bowel, colon }\end{array}$ & $\begin{array}{l}\text { Hamartomatous } \\
\text { polyps } \\
\text { (juvenile type) } \\
\text { exhibiting glandular } \\
\text { hyperplasia, cystic } \\
\text { dilation, mucosal edema, } \\
\text { and eosinophilic } \\
\text { inflammation }\end{array}$ & $\begin{array}{l}\text { Alopecia, dermal } \\
\text { hyperpigmentation, } \\
\text { onychodystrophy, } \\
\text { diarrhea, } \\
\text { protein-losing } \\
\text { enteropathy, } \\
\text { dysgeusia }\end{array}$ & $\begin{array}{l}\text { Cachexia, } \\
\text { colon cancer } \\
\text { (mostly } \\
\text { left-sided) }\end{array}$ \\
\hline Peuz-Jeghers & $10-30$ & $\begin{array}{l}\text { Autosomal } \\
\text { Dominant }\end{array}$ & $\begin{array}{l}\text { Stomach, small } \\
\text { bowel, colon }\end{array}$ & $\begin{array}{l}\text { Hamartomas in th } \\
\text { e stomach and small } \\
\text { bowel, adenomatous } \\
\text { polyps in the colon }\end{array}$ & $\begin{array}{l}\text { Mucocutaneous } \\
\text { melanosis }\end{array}$ & $\begin{array}{l}\text { Colon, gastric, } \\
\text { pancreatic, } \\
\text { breast, and/or } \\
\text { gynecologic } \\
\text { cancers }\end{array}$ \\
\hline $\begin{array}{l}\text { Familial } \\
\text { adenomatosus } \\
\text { polyposis }\end{array}$ & $15-20$ & $\begin{array}{l}\text { Autosomal } \\
\text { Dominant }\end{array}$ & $\begin{array}{l}\text { Stomach, small } \\
\text { bowel, colon }\end{array}$ & Adenomas & $\begin{array}{l}\text { Hypertrophy of } \\
\text { retinal pigment } \\
\text { epithelium, } \\
\text { brain tumors } \\
\text { (Turcot syndrome), } \\
\text { epidermoid cysts, } \\
\text { mandibular osteomas, } \\
\text { desmoids, thyroid tumors } \\
\text { (Gardner syndrome) }\end{array}$ & $\begin{array}{l}\text { Colon, } \\
\text { duodenal, } \\
\text { and/or thyroid } \\
\text { cancers }\end{array}$ \\
\hline Cowden disease & $9-20$ & $\begin{array}{l}\text { Autosomal } \\
\text { Dominant }\end{array}$ & $\begin{array}{l}\text { Stomach, small } \\
\text { bowel, colon }\end{array}$ & Hamartomas & $\begin{array}{l}\text { Facial trichilemmomas, } \\
\text { macrocephaly, } \\
\text { mucocutaneous lesions, } \\
\text { acral keratoses, thyroid } \\
\text { disease, breast disease }\end{array}$ & $\begin{array}{l}\text { Breast, thyroid, } \\
\text { reproductive } \\
\text { organ, and/or } \\
\text { colon cancers }\end{array}$ \\
\hline
\end{tabular}

CCS, Cronkhite-Canada syndrome. Adapted from Seshadri et al., 2012. ${ }^{4}$

Table 3. Laboratory findings after 2 months of treatment.

\begin{tabular}{lcc}
\hline Laboratory variable & Value & Normal range \\
\hline Total protein $(\mathrm{g} / \mathrm{dL})$ & 6.1 & $6.2-8.7$ \\
Serum albumin $(\mathrm{g} / \mathrm{dL})$ & 4.35 & $4-4.76$ \\
$25 \mathrm{OH}$ vitamin D $(\mathrm{nMol} / \mathrm{L})$ & 45 & $62-199$ \\
Vitamin B12 & $>700$ & $190-700$ \\
Ferritin $(\mathrm{pMol} / \mathrm{L})$ & 238 & $54-755$ \\
Copper $(\mathrm{uMol} / \mathrm{L})$ & 11.7 & $11.8-22$ \\
Zinc $(\mathrm{uMol} / \mathrm{L})$ & 12.3 & $9-15.7$ \\
Potassium $(\mathrm{mEq} / \mathrm{L})$ & 3.7 & $3.3-5.4$ \\
Magnesium $(\mathrm{mg} / \mathrm{dL})$ & 2.2 & $1.5-2.6$ \\
\hline
\end{tabular}


was suspended or reduced. Because of this reason, alternative regimens were used, such as azathioprine $2 \mathrm{mg} / \mathrm{kg}$ /day, obtaining longer lasting positive clinical responses. ${ }^{1-3,5-10,12}$ Other possible alternative treatments used were: $\mathrm{H} 2$ blockers, proton pump inhibitors, antibiotics, but with poor results and limited to patient with $H$. pylori co-infection. ${ }^{13}$ Due to the common symptoms, such as impaired absorption, malnutrition, and immune-suppression, an appropriate nutritional support with concentrated vitamins and minerals must be added in addition to the treatment. Recent evidence suggests that a total parenteral nutrition should be planned to improve clinical outcome of these patients. ${ }^{14}$

There is a unanimous consensus on prevention screening programs for colorectal cancer in these patients. However, to date, no univocal results is available, explaining whether polyps, observed in subjects with CCS, are really precancerous lesions, although some studies showed that the risk of this malignancy is higher in these patients. ${ }^{4}$ In the largest epidemiological study available to date, a rather high incidence of colon rectal cancer has been reported ( $71 \%$ adenomas, $14 \%$ carcinomas)..$^{12}$ Unfortunately, the majority of polyps limit the possibility of performing a biopsy all these lesions. On the whole, these data strongly suggests that an adequate follow-up is required in this patient, including colonoscopy after the end of treatment. Appropriate therapy may cause the regression of inflammatory and hyperplastic polyps, making it easier to distinguish which polyps are at greater risk of neoplastic evolution. ${ }^{3}$ Therefore, they can be removed and used for histological assessment.

\section{Conclusions}

Cronkhite-Canada syndrome is a rare, acquired gastrointestinal polyposis syndrome with a typical dermatologic manifestation. The polyps in CCS are endoscopically similar to several other polyposis syndromes, but can present some histological peculiarities. The two milestones of therapy include immunosuppression with steroids and an appropriate nutritional support. There is evidence for an increased risk of colorectal neoplasia, but the early detection of this malignancy is difficult, therefore decisions concerning surveillance and treatment need to be made on case-by-case basis.

\section{References}

1. Cronkhite LW Jr, Canada WJ. Generalized gastrointestinal polyposis: an unusual syndrome of polyposis, pigmentation, Alopecia, and onychotophia. N Engl J Med 1955;252:1011-5.

2. Goto A. Cronkhite-Canada syndrome: epidemiological study of 110 cases reported in Japan. Nihon Geka Hokan 1995;64:3-14.

3. Sweetser S, Ahlquist DA, Neal K, et al. Clinicopathologic feautures and treatment outcomes in CronkhiteCanada syndrome: support for autoimmunity. Dig Dis Sci 2012;57:496-502.

4. Seshadri D, Karagiorgios N, Hyser MJ. A case of Cronkhite-Canada syndrome and a review of gastrointestinal polyposis syndromes. Gastroenterol Hepatol (N Y) 2012;8:197-201.

5. Takakura M, Adachi H, Tsuchihashi N, et al. A case of Cronkhite-Canada syndrome markedly improved with mesalazine. Dig Endosc 2004;16:74-8.

6. Ward EM, Wolfsen HC. Review article: the non-inherited gastrointestinal polyposis syndromes. Aliment Pharmacol Ther 2002;16:333-42.

7. Jenkins D, Stephenson PM, Scott BB. The CronkhiteCanada syndrome: an ultrastuctural study of Pathogenesis. J Clin Pathol 1985;38:271-6.

8. Blonsky WC, Furth EE, Kinosian BP, et al. A case of Cronkhite-Canada syndrome with taste disturbances as a leading complaint. Digestion 2005;71:201-5.

9. Daniel ES, Ludwig SL, Lewin KJ, et al. The CronkhiteCanada syndrome: an analysis of clinical and pathological features and therapy in 55 patients. Medicine (Baltimore) 1982;61:293-309.

10. Burke AP, Sobin LH. The pathology of CronkhiteCanada polyps. A comparison to juvenile polyposis. Am J Surg Pathol 1989;13:940-6.

11. Watanabe-Okada E, Inazumi T, Matsukawa H, Ohyama M. Histopathological insights into hair loss in Cronkhite-Canada syndrome: diffuse anagen-telogen conversion precedes clinical hair loss progression. Australas J Dermatol 2013. [Epub ahed of print].

12. Sweetser S, Boardman LA. Cronkhite-Canada syndrome: an acquired condition of gastrointestinal polyposis and dermatologic abnormalities. Gastroenterol Hepatol (N Y) 2012;8:201-3.

13. Ward EM, Wolfsen HC. Pharmacological management of Cronkhite-Canada syndrome. Expert Opin Pharmacother 2003;4:385-9.

14. Ferney DM, DeScheryver-Kecskemeti K, Clouse RE. Treatment of Cronkhite-Canada syndrome with home parenteral nutrition. Ann Intern Med 1986;104:588. 